8. Видт И.Е. Образование как феномен культуры: эволюция образовательных моделей в историко-культурном пространстве. Дисс. ...докт.пед.н. -Тюмень,2003.

9. Волков Г.П. Чувашская народная педагогика. -Чебоксары,1958.

10. Конструктивная роль педагогической культурологи // Вопросы культурологи. -2007. -№10.

11. Научно-образовательная школа «Педагогическая культурология» профессора В.Л.Бенина // Научно-образовательные школы Урала. Екатеринбург: Изд-во «Раритет», 2012.

12. Педагогика: педагогические теории, системы, технологии. Учеб. пособ. для студентов средних педагогических учебных заведений. -М.,1999.

13. Педагогическая культура. Коллективная монография./ Отв. Редакторы В.Л.Бенин, В.В.Власенко. -СПб.: Эйдос, 2012.

14. Педагогический энциклопедический словарь. М.: Большая рос. энцикл. 2002.

15. Флиер А.Я. Конструктивная роль педагогической культурологи // Вопросы культурологи. -2007. -№10.

Зайко А.П.,

г. Челябинск

\title{
СОЦИАЛЬНАЯ АКТИВНОСТЬ КАК СОЦИОЛОГИЧЕСКАЯ
}

\section{КАТЕГОРИЯ}

Социальная активность студенчества в современных условиях становится одной из важнейших в теоретическом и практическом отношении проблем в социологической науке. Студенчество как социальнодемографическая группа всегда была одной из самых популярных объектов изучения среди социологов. Это гетерогенная, мобильная, весьма любопытная, с точки зрения исследователя, группа любого общества и культуры. Особенно интересной она становится в условиях социально- 
экономической, политической трансформации общества. Современное российское студенчество становится одним из самых активных и властных социальных субъектов. От его экономического, политического и культурного выбора во многом зависит развитие общества. Вместе с тем, некоторые проблемы, касающиеся жизнедеятельности студентов, на наш взгляд, неоправданно оказываются вне поля зрения исследователей. К таким проблемам относятся вопросы, связанные с социальной активностью студентов. Однако эта проблематика активно изучалась в 80-е годы XX столетия в трудах таких исследователей, как Е.А. Ануфриев, О. Гуломов, Е.В. Грунт, В.И. Липский, В.Г. Мордкович, Н.Э. Майн и др. [1]. Мы полагаем, что в современных условиях во многом по-новому необходимо подходить к исследованию проблем активности социального субъекта. Иначе говоря, необходимо более глубоко изучать направления и формы социальной активности студентов, объективные и субъективные факторы ее формирования, механизмы их взаимодействия.

Анализ имеющихся в литературе работ позволяет судить о том, что далеко не все проблемы социальной активности студенчества исследуются с достаточной полнотой, да и само понятие «социальная активность» до сих пор еще не имеет строгой научной трактовки. В частности, до настоящего времени нет специальных работ, в которых комплексно исследовалась бы социальная активность студентов в условиях трансформации российского общества. На практике все формы активности находятся в диалектическом единстве, и их комплексное исследование дает возможность предусмотреть гармоничное развитие всех видов деятельности студентов, усилить влияние этой деятельности на формирование личности.

Как мы отмечали выше, проблема активности не нашла еще однозначного решения в философской и социологической литературе. На сегодняшний день сложилось несколько подходов к рассмотрению данного понятия. Рассмотрим деятельностный подход к анализу понятия « социальная активность». В рамках этого подхода сложилось несколько 
направлений. Общим, объединяющим моментом данного подхода является то, что социальная активность рассматривается в связи с деятельностью личности [2]. Методологически, на наш взгляд, этот подход является вполне правомерным, так как деятельность выступает субстанцией социальной формы движения материи. В данном случае исходным моментом для понимания природы активности выступает положение К. Маркса о том, что первым и самым важным из природных свойств материи является движение, как стремление, «жизненный дух», «мучение материи» [3]. Ф. Энгельс уточняет, что «мучение» - это активное начало, возникающее из самопроизвольного развития вещи, отношения или личности. Материя развивается в силу присущих ей внутренних противоречий, что и является источником самодвижения. В свою очередь, материя в своем историческом движении порождает различные виды активности (механическая, биологическая, химическая, социальная и пр.). Активность имеет свою конкретную форму выражения, которая определяется способом взаимосвязи субъекта с окружающей средой. Во всех случаях активность выступает как выражение единства внутреннего ( самого субъекта) и внешнего (среды). В этом плане конкретное выражение социальная активность получает в социальной деятельности субъекта. Так, Н.Н. Белякович под социальной активностью понимает « способность субъекта к совокупному деятельному отношению с объективной действительностью, обусловленному конкретноисторическими условиями» [4]. Конечно, реализуясь в деятельности, социальная активность выступает как процесс взаимодействия субъекта с окружающей его социальной реальностью. В ходе такого взаимодействия наряду с преобразованием природы происходит преобразование самой социальной реальности и человека. Однако мы не согласны с тем, между отношением и деятельностью существует однозначное соответствие . Что касается социальной активности, то она связана с производством и воспроизводством социальных связей и отношений и реализуется в социально-преобразующей деятельности. По отношению к отдельному 
человеку она может быть охарактеризована как его способность к включению в социальные отношения, определению своего места в них и их воспроизводству через самореализацию себя как личности. Именно в понятии «личность» человек раскрывается со стороны своей сущности, поэтому и в категории «социальная активность» находит выражение социальное содержание его способности и подготовленность к той или иной социальной деятельности. Таким образом, социальная активность личности, на наш взгляд, определяется так же и таким фактором, как наличие способностей к той или иной деятельности, то есть в ней всегда заключена именно потенция, способность. Однако, сама эта потенция, способность должна быть необходимо связанной с самой действительностью, в которой реализуются задатки, возможности, данные человеком природой и обществом. Следовательно, социальная активность личности выступает как процесс реализации способностей, задатков человека в практической , предметно-преобразующей деятельности в конкретной социальной среде. К сожалению, данное определение не учитывает этот важный момент.

В рамках данного подхода многие авторы сущность социальной активности сводят к особому содержанию деятельности, которое характеризуется «повышенной интенсивностью и творчеством» [5]. Е.А. Ануфриев дает следующее определение социальной активности « .... Сознательное, творческое отношение к трудовой и общественнополитической деятельности», в результате которой обеспечивается глубокая и полная реализация личности» [6]. Однако, думается, что при таком понимании социальной активности, во-первых, размываются границы этого понятия и его специфика. Во-вторых, может сложиться неверное впечатление о том, что активность личности складывается только из положительно направленных творческих действий личности. В- третьих, здесь не учитываются другие виды социальной деятельности личности, например, досуговая, образовательная и т.д., где так же присутствует творческий компонент. При анализе социальной активности А.К. Рычков и И.Б. 
Кишинец учитывают различные виды деятельности личности, однако связывают их с творчеством, результативностью и интенсивностью [7]. Мы полагаем, что выделение творчества в качестве определяющего критерия активности личности не вполне правомерно. Это связано с тем, что творчество, как правило, связано с созданием чего-либо нового и направлено на создание новых ценностей. Вместе с тем, в процессе творческой деятельности может быть получен уже известный результат, но, который может оказаться новым для личности, либо этот результат может быть получен новым для личности способом. Примером этого служат прогрессивные технологии, с помощью которых более экономичным способом могут быть произведены ранее известные материалы, изготовлены ране известные предметы и пр. Творческий компонент присутствует и в рационализаторской, и в образовательнолй деятельности. В процессе творческой деятельности человек часто выходит за пределы своих ранее выполняемых функций, ролей и начинает их совершенствовать. Но, не каждый человек в состоянии внести самобытный творческий вклад в тот или иной вид социальной деятельности. Многие люди всю свою жизнь занимаются рутинным, монотонным трудом, но при этом могут проявлять свою активность в других сферах, опять же, не проявляя творчества. Поэтому мы рассматриваем творчество не только как качественную характеристику социальной активности, но и как высшую ее форму.

В рамках данного подхода наиболее распространенным является понимание социальной активности как «меры дееспособности человека». [7]. В. А. Смирнов под социальной активностью рассматривает «меру социальной деятельности , выражающую характер ( общественное значение) и масштабы производимых в ходе и вследствие этой деятельности изменений в окружающей личность (группу) природной и социальной среде, а так же изменений в самой личности (группе) [8]. Мы полагаем, что в данном определении автор верно говорит о том, что в этой мере выражается конкретность, направленность и содержание социальной деятельности 
личности или группы, а так же ее цель. Однако возникает вопрос о том, что есть мера? Как ее замерить? Любая мера предполагает эталон, образец некой социальной активности личности или группы. Вопрос о мере в данных определениях остается открытым. С другой стороны, рассмотрение меры (раскрытие того, что есть мера) ведет к расширению понятия «социальная активность». Вместе с тем, ряд исследователей предлагают при рассмотрении социальной активности учитывать количественные, либо качественные характеристики меры дееспособности личности, что так же расширяет границы исследуемого нами понятия.

Подводя итоги анализа деятельностного подхода к анализу социальной активности личности, можно сделать следующие выводы:

1) Он сыграл определенную положительную роль в изучении проблемы активности в социологии и философии, так как показал связь социальной активности и социальной деятельности:

2) Вместе с тем, в определениях социальной активности как «меры дееспособности», интенсивности деятельности, творчества и т.д. раскрываются лишь определенные стороны этой категории. Каждый из выделяемых исследователями признаков не имеет обобщенного характера , поэтому сущность активности остается не раскрытой.

Мы рассматриваем социальную активность как социальное качество личности, реализующееся в различных видах самодеятельности, в процессе которой происходит самореализация личности, обусловленная объективными и субъективными факторами. Такое определение, на наш взгляд, позволяет: во-первых, указать на необходимость рассмотрения социальной активности в двух значениях: как социального качества личности и как определенной характеристики ее деятельности - самодеятельности, как единство личного и общественного;

Во-вторых, позволяет показать, что возможности проявления социальной активности обусловлено исторически - объективными факторами, а так же интересами самой личности. В-третьих, при проявлении 
социальной активности происходит самореализация личности в той или иной социальной сфере.

Литература

1. См. Ануфриев Е.А. Социальная активность личности,М., 1971; Грунт E. В. Социальная активность рабочего класса службы быта// Общественная активность личности в условиях перестройки. Челябинск, 1991; Мордкович В.Г. Социальная активность личности. М., 1979 и др.

2. См. Арефьева Г.С. Социальная активность. М., 1974; Белякович Н.Н. Социальная активность личности. Минск, 1978; Гольдентрихт С.С. Творчество и социальное познание, М.1999 и др.

3. Маркс К. , Энгельс Ф. Соч. Т.22. С.300

4. ; Белякович Н.Н. Социальная активность личности. Минск, 1978.С.6

5. Ануфриев Е.А. Социальный статус и активность личности, М, 1984; Смирнов Н.П. Советский рабочий : формирование творческой личности. М., 1987 и др.

6. Ануфриев Е.А. Социальный статус и активность личности, М, 1984. С. 234

7. Формирование социально- активной личности : сущность, проблемы. М., 1986 и др.

8. Смирнов Н.П. Советский рабочий : формирование творческой личности. М., 1987 , С.25

Злотникова Л.М., г. Гомель, Республика Беларусь ЭКОНОМИЧЕСКАЯ КУЛЬТУРА В СИСТЕМЕ ЦЕННОСТЕЙ ОБЩЕСТВЕННОГО РАЗВИТИЯ

Понятие культура в общественном и научном сознании чаще всего отождествляется с отношениями между людьми. И в тоже время сложно 